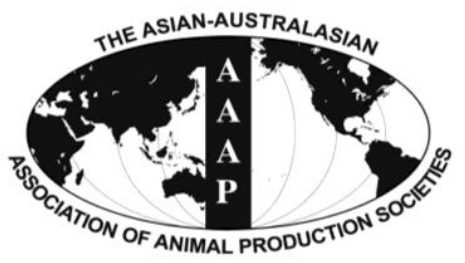

Asian Australas. J. Anim. Sci.

Vol. 26, No. 11 : 1637-1643 November 2013

http://dx.doi.org/10.5713/ajas.2013.13174

www.ajas.info

pISSN 1011-2367 elSSN 1976-5517

\title{
Slaughtering Age Effect on Carcass Traits and Meat Quality of Italian Heavy Draught Horse Foals
}

\author{
P. De Palo*, A. Maggiolino, P. Centoducati, and A. Tateo \\ Department of Veterinary Medicine, S.P. per Casamassima, km 3, 70010 Valenzano (BA), Italy
}

\begin{abstract}
The present work describes the effect of slaughtering age on horse carcass traits and on meat quality. Eighteen male Italian heavy draught horse (IHDH) breed foals were employed in the study. Soon after foaling they were randomly subdivided in 3 groups according to 3 age at slaughtering classes: 6 months old, 11 months old and 18 months old. Live weight, hot carcass weight and dressing percentage of each animal were recorded. After slaughtering, meat samples were collected from Longissimus Dorsi muscle between 13th and 18th thoracic vertebra of each animal and then analyzed. The right half carcass of each animal was then divided in cuts. Each one was subdivided into lean, fat and bones. Then, the classification of the lean meat in first and second quality cuts was performed according to the butchers' customs. Older animals were characterized by a lower incidence of first quality cuts ( $<<0.01)$ on carcass. Younger animals showed greater content in protein $(\mathrm{p}<0.01)$. Fatty acid profile showed an increasing trend of PUFA connected to the increasing of slaughtering age $(\mathrm{p}<0.05)$. The unsaturation index of intramuscular fatty acids was not affected by slaughtering age, confirming that horse meat, if compared to beef, is more suitable from a nutritional point of view. Season influenced reproduction, birth as well as production aspects of this species. The different slaughtering age could represent the way to produce meat of IHDH foals during the entire year without change in the qualitative standard expected by consumers. (Key Words: Horse Meat, Fatty Acid Profile, Meat Quality, Slaughtering Age)
\end{abstract}

\section{INTRODUCTION}

Horse meat consumption is marginal if compared with other conventional types of meat such as beef, chicken or pork (Lombardi-Boccia et al., 2005). For many years, in Italy horse meat consumption has been the highest among all European Community countries (Martuzzi et al., 2001) and many efforts have been made to develop the national production of horse meat both from a qualitative and quantitative points of view (De Palo et al., 2012). Currently the production of horse meat in Italy is mainly obtained from breeds such as the Italian Heavy Draught Horse (IHDH). Many studies on this horse breed demonstrated that this breed is particularly suitable for both meat (Tateo et al., 2005; 2009; 2013) and milk production (Centoducati et al., 2012).

Season influenced reproduction, birth and noticeably many kinds of production aspects of such species. Otherwise, all over the year horse meat consumption is not equally distributed, being a concern the seasonal

\footnotetext{
* Corresponding Author: Pasquale De Palo. Tel: +39-080544 3919, Fax: +39-0804679925, E-mail: pasquale.depalo@uniba.it Submitted Mar. 27, 2013; Accepted Apr. 29, 2013; Revised Jun. 14, 2013
}

reproduction activity of mares. Hence, in order to ensure the horse meat availability to the market without any suspension, the slaughter period might be more thoroughly extended, by planning regularly the transport of raised horses to slaughtering facilities. This might be a way to produce meat of IHDH foals during the entire year without otherwise change the qualitative standard expected by consumers. Furthermore, nowadays consumers are more health conscious and demand supplementary high quality food products. For instance, they required leaner meat than in the past (Franco et al., 2013). The nutritional properties of horse meat are wide owing to its excellent chemical characteristics, including low fat for the low level of saturated fatty acids, and the richness in iron. Essentially, the greatest health benefits to consumer comes from the particular high content of unsaturated fatty acids, which confer a beneficial dietetic fatty acid profile (Badiani et al., 1997; Tateo et al., 2008).

In this context, the aim of this study was to evaluate the potential helpful effects of slaughtering age, considering 18 months as the oldest slaughtering age, on horse meat characteristics described above. 


\section{MATERIALS AND METHODS}

\section{Animals}

A total of 18 males IHDH breed foals were employed in the study. Soon after foaling, they were randomly subdivided in 3 groups according to age at slaughtering classes: 6 months old, 11 months old and 18 months old. The foals regularly assumed colostrum and were naturally suckled. From their second day of life, they followed their dams to the grazing areas for almost $6 \mathrm{~h} / \mathrm{d}$. The foals were weaned at 4 months old, and then were kept in 3 indoor stalls (one for each experimental group), with a space allowance of $6 \mathrm{~m}^{2}$ per head. Each group received a ration subdivided in three daily meals. The composition of the feed administered was the same during all the experimental trial and for the three experimental groups. It was composed with $35 \%$ of oat hay and $65 \%$ of commercial feed (rolled corn $33 \%$, soybean meal $21 \%$, wheat bran $17 \%$, rolled barley $13.5 \%$, rolled oats $13.5 \%$, vitamin and mineral integration $2 \%$ ).

\section{Slaughtering and treatment of samples}

Live weight (LW) of each animal was measured $1 \mathrm{~h}$ before slaughtering. They were slaughtered in a national accredited slaughterhouses, according to current EU regulations (Council Directive of the European Union 95/221EC).

After slaughtering, hot carcass weight $(\mathrm{CW})$ was measured and dressing percentage (DP) was calculated, then carcasses were kept in a chilling room at $4^{\circ} \mathrm{C}$ for $48 \mathrm{~h}$. Samples of Longissimus dorsi (LD) muscle between 13th and 18th thoracic vertebra (about $500 \mathrm{~g}$ for each sample) were taken for analysis. These samples were transported at $4^{\circ} \mathrm{C}$ to the laboratory and analyzed within two hours. Moreover, the right half carcass was dissected in cuts and each one was subdivided into lean, fat and bones according to De Palo et al. (2009). The classification of the lean meat in first and second quality cuts was performed according to the traditionally Italian butchers' customs: hind leg, neck, briskets and bacon were classified as second quality cuts, steaks, loin, fore leg and tenderloin were classified as first quality cuts.

\section{Meat analysis}

Meat proteins were measured with the ISO 937:1978 method (ISO, 1978); intramuscular fat was determined with the ISO 1443:1973 method (ISO, 1973) and ash was calculated with the ISO 936:1998 method (ISO, 1998). Every muscle and subcutaneous tissue sample was homogenized with a mixture chloroform and methanol (1:2, $\mathrm{vol} / \mathrm{vol}$ ) solution for the extraction of total lipids from intramuscular and subcutaneous fat, according to the method described by Bligh and Dyer (1959).
The water holding capacity (WHC) was measured using the centrifugation method according to Bouton et al. (1971). $0.3 \mathrm{~g}$ specimen was collected from each sample and then was centrifuged at $60,000 \times \mathrm{g}$ for $1 \mathrm{~h}$. After centrifugation, the samples were dried and weighed again, and the centrifugation loss was calculated as the difference in weight before and after centrifugation.

For the cooking loss determination, cubic meat pieces with $1.5 \mathrm{~cm}$ per side were weighed (initial weight, $\mathrm{Wi}$ ) and then cooked in plastic bags in water bath at $80^{\circ} \mathrm{C}$ until they reached the internal temperature of $75^{\circ} \mathrm{C}$, measured by a copper constantin fine-wire thermocouple fixed in the geometrical center of the sample (Model 5SC-TT-T-30-36, Omega Engineering Inc., Stamford, CT). Cooked samples were cooled, dried from fluids and reweighed (final weight, Wf). The cooking loss was calculated as a percentage of weight loss: [(Wi-Wf)/Wi] $\times 100$ (Bertram et al., 2003).

Post thawing losses were calculated as the difference in weight before freezing and after thawing. Each sample was weighed before the freezing process (initial weight, $\mathrm{Wi}$ ) and after thawing process. The post thawing losses were calculated according the following formula: [(Wi-Wf $/ \mathrm{Wi}]$ $\times 100$.

Each cooked lean sample was tested for Warner-Bratzler Shear Force (WBSF). The samples were cooked in plastic bags up to an internal temperature of $70^{\circ} \mathrm{C}$ for $3 \mathrm{~min}$ in a water bath at $85^{\circ} \mathrm{C}$ (measured with a copper constantin finewire thermocouple, Model 5SC-TT-T-30-36, Omega Engineering Inc., Stamford, CT, fixed in the geometrical center of the sample). The WBSF was measured using an Instron 1140 apparatus (Instron, High Wycombe, UK) interfaced with a computer, using a crosshead speed of 50 $\mathrm{mm} / \mathrm{min}$ and a load cell of $50 \mathrm{~N}$. The cut sample had a cylindrical shape with a diameter of $1.27 \mathrm{~cm}$. The cut was parallel to the muscle fiber direction. The force-deformation curve obtained was used to calculate meat hardness. Shear force was determined perpendicular to the fiber direction. Each sample was sheared 3 times, and the arithmetic mean of the data registered from each sample was subjected to further statistical analysis.

Fatty acid methyl esters (FAME) were prepared by transesterification, using methanol in the presence of $3 \%$ hydrochloric acid in methanol (vol/vol). Fatty acid methyl esters were analyzed using a Trace GC Thermo Quest Gas Chromatograph (Thermo Electron, Rodano, Milan, Italy) equipped with a flame ionization detector. The derivatives were separated on a capillary column (Supelco SP-2380 fused-silica column, 30-m length, 0.25 -mm i.d., and 0.20$\mathrm{mm}$ film thickness). The injector and the detector temperatures were held at $260^{\circ} \mathrm{C}$. Column oven program temperatures were as follows: $\mathrm{T} 1=80^{\circ} \mathrm{C}$ hold $1 \mathrm{~min} ; \mathrm{T} 2=$ $150^{\circ} \mathrm{C}$ ramp at $15^{\circ} \mathrm{C} / \mathrm{min}$, hold $2 \mathrm{~min} ; \mathrm{T} 3=220^{\circ} \mathrm{C}$ ramp at $5^{\circ} \mathrm{C} / \mathrm{min}$, hold $2 \mathrm{~min} ; \mathrm{T} 4=250^{\circ} \mathrm{C}$ ramp at $15^{\circ} \mathrm{C} / \mathrm{min}$, hold 5 
min. The flow rate of the carrier gas $(\mathrm{He})$ was set at 0.8 $\mathrm{mL} / \mathrm{min}$. Identifications of FAME were based on the retention times of reference compounds (Sigma-Aldrich, St. Louis, MO) and mass spectrometry. Fatty acid composition was expressed as the percentage of total FAME.

Collagen was extracted following the Sörensen (1981) method. Determination of 4-hydroxyproline was performed according to the procedure suggested by Kindt et al. (2003) using electrospray mass spectrometry (LCQ Thermo Electron, CA, Waltham, MA) to avoid any derivatization step.

\section{Statistical analysis}

The collected data were subjected to analysis of variance by employing the Statistical Analysis System software (SAS, 1998) and the General Linear Model (GLM) procedure, using the age at slaughtering as independent variable. All the results here reported were expressed as least square means and mean standard errors.

\section{RESULTS AND DISCUSSION}

The slaughtering performances are reported in Table 1. Live weight (LW) was naturally affected by age at slaughtering $(\mathrm{p}<0.001)$ showing an increasing trend. Consequently, the live weight trend affected carcass weight (CW), which increased along as the increasing of slaughtering age $(\mathrm{p}<0.001)$. On the contrary, dressing percentage (DP) was not affected $(p>0.05)$, although there was an increasing trend with the raising slaughtering age. Similar results were reported by Franco et al. (2013) and Lanza et al. (2009) studying the effect of cross breeding and finishing diet on horse carcass. Authors observed a significant effect on LW and CW but not on DP. Dissimilar results were reported by Sarries and Beriain (2005). By studying the slaughtering of Barguete horses at 16 and 24 months they did not observed any effect of age at slaughter on CW; however a significant effect was observed on DP. Mainly, DP values obtained by IHDH foals (70.03 to $73.90 \%$ ) were higher than the $63.3 \%$ observed by Sarries and Beriain (2005) in Barguete foals, related to the $59 \%$ observed in Sanfratellano horses and Haflinger horses, and then to the $50 \%$ observed by Franco et al. (2013) in Galician Mountain horses.

The examination carcass quality showed higher incidence of front quarter, a lower incidence of hind quarter and lean in horses slaughtered at 18 months $(\mathrm{p}<0.001)$. Moreover, those carcasses showed an increasing fat incidence with the age raise at slaughtering $(\mathrm{p}<0.001)$. However, lean and bone incidence of IHDH foal carcasses reported in this paper were respectively greater and lower than that observed by Znamirowska and Stanislawczyk (2005) and Znamirowska (2005) in polish foals. In fact, they showed that lean incidence on horse carcass ranged from $68.45 \%$ to $60.63 \%$, and was lower than what was observed in IHDH foals (68.23 to $75.83 \%$ ). However, horse represented the species with higher lean incidence compared to other species employed for meat production (Znamirowska, 2005). Horses slaughtered at 18 months were characterized by a higher percentage of fat $(\mathrm{p}<0.01)$ (Table 2) and a lower incidence of meat or bone or both meat and bone $(\mathrm{p}<0.01)$, aspects more evident on hind and fore leg, neck and briskets. These results could be explained by a different use of metabolic energy by foals of different age. In fact, while the older animals tended to convert energy in adipose tissue, the younger animals tended to transfer energy in muscle (Tateo et al., 2008; De Palo et al., 2009). These reasons could explain the lower incidence of

Table 1. Live weight (LW), carcass weight (CW), dressing percentage (DP), carcass composition and first quality cuts incidence of foals slaughtered at 6,11 , and 18 months

\begin{tabular}{|c|c|c|c|c|c|}
\hline & \multicolumn{3}{|c|}{ Age } & \multirow{2}{*}{ Significance } & \multirow{2}{*}{ SEM } \\
\hline & 6 months & 11 months & 18 months & & \\
\hline LW (kg) & $320.58^{\mathrm{A}}$ & $456.45^{\mathrm{B}}$ & $568.87^{\mathrm{C}}$ & $* * *$ & 6.13 \\
\hline $\mathrm{CW}(\mathrm{kg})$ & $223.74^{\mathrm{A}}$ & $329.42^{\mathrm{B}}$ & $421.58^{\mathrm{C}}$ & $* * *$ & 3.10 \\
\hline $\mathrm{DP}(\%)$ & 70.03 & 72.60 & 73.90 & ns & 1.03 \\
\hline \multicolumn{6}{|l|}{ Carcass composition (\%) } \\
\hline Front quarter & $35.12^{\mathrm{A}}$ & $35.43^{\mathrm{A}}$ & $43.57^{\mathrm{B}}$ & $* * *$ & 0.43 \\
\hline Hind quarter & $65.21^{\mathrm{A}}$ & $65.07^{\mathrm{A}}$ & $56.10^{\mathrm{B}}$ & $* * *$ & 0.66 \\
\hline Lean & $75.83^{\mathrm{A}}$ & $75.03^{\mathrm{A}}$ & $68.23^{\mathrm{B}}$ & $* * *$ & 0.79 \\
\hline Fat & $12.84^{\mathrm{A}}$ & $15.95^{\mathrm{B}}$ & $19.98^{\mathrm{C}}$ & $* * *$ & 0.41 \\
\hline Bone & $11.68^{\mathrm{A}}$ & $9.55^{\mathrm{B}}$ & $11.45^{\mathrm{A}}$ & $* * *$ & 0.36 \\
\hline \multicolumn{6}{|l|}{ First quality incidence (\%) } \\
\hline 1st quality ${ }^{1}$ on carcass & $58.13^{\mathrm{Aa}}$ & $60.57^{\mathrm{Ab}}$ & $52.80^{\mathrm{B}}$ & $* * *$ & 0.61 \\
\hline 1st quality on front quarter & $57.42^{\mathrm{A}}$ & $55.78^{\mathrm{a}}$ & $53.77^{\mathrm{Bb}}$ & $* *$ & 0.65 \\
\hline 1st quality on hind quarter & $69.36^{\mathrm{A}}$ & $73.52^{\mathrm{Ba}}$ & $70.93^{\mathrm{b}}$ & $* *$ & 0.75 \\
\hline
\end{tabular}

Different letters in the same line show statistical differences $\left({ }^{\mathrm{A}, \mathrm{B}, \mathrm{C}} \mathrm{p}<0.01 ;{ }^{\mathrm{a}, \mathrm{b}} \mathrm{p}<0.05\right)$. Significance: $* * * \mathrm{p}<0.001,{ }^{*} \mathrm{p}<0.01, \mathrm{~ns}=\mathrm{Not}$ significant.

${ }^{1} 1$ st quality cuts $=$ Steacks I-VIII, Loin+Steacks IX-XVIII, Fore leg and Tenderloin. 
Table 2. Cuts incidence (\%) and their tisular composition (\%) of foals slaughtered at 6,11 and 18 months

\begin{tabular}{|c|c|c|c|c|c|}
\hline & \multicolumn{3}{|c|}{ Age } & \multirow{2}{*}{ Significance } & \multirow{2}{*}{ SEM } \\
\hline & 6 months & 11 months & 18 months & & \\
\hline Hind leg & $17.47^{\mathrm{A}}$ & $15.32^{\mathrm{B}}$ & $15.57^{\mathrm{B}}$ & $* * *$ & 0.17 \\
\hline Meat (\%) & $68.56^{\mathrm{a}}$ & $71.27^{\mathrm{b}}$ & $68.05^{\mathrm{a}}$ & $*$ & 0.79 \\
\hline Fat $(\%)$ & $9.93^{\mathrm{A}}$ & $9.77^{\mathrm{A}}$ & $14.10^{\mathrm{B}}$ & $* * *$ & 0.30 \\
\hline Bone (\%) & $21.87^{\mathrm{A}}$ & $19.47^{\mathrm{B}}$ & $17.52^{\mathrm{C}}$ & $* * *$ & 0.32 \\
\hline Neck & $9.48^{\mathrm{A}}$ & $8.98^{\mathrm{A}}$ & $13.75^{\mathrm{B}}$ & $* * *$ & 0.22 \\
\hline Meat $(\%)$ & $80.42^{\mathrm{Aa}}$ & $77.37^{\mathrm{Ab}}$ & $71.15^{\mathrm{B}}$ & $* * *$ & 0.97 \\
\hline Fat $(\%)$ & $7.64^{\mathrm{A}}$ & $11.12^{\mathrm{B}}$ & $19.77^{\mathrm{C}}$ & $* * *$ & 0.24 \\
\hline Bone $(\%)$ & $12.28^{\mathrm{A}}$ & $12.02^{\mathrm{A}}$ & $8.80^{\mathrm{B}}$ & $* * *$ & 0.38 \\
\hline Briskets I-VIII & $3.71^{\mathrm{A}}$ & $6.42^{\mathrm{B}}$ & $9.78^{\mathrm{C}}$ & $* * *$ & 0.07 \\
\hline Meat and bone (\%) & $93.73^{\mathrm{A}}$ & $82.32^{\mathrm{B}}$ & $83.55^{\mathrm{B}}$ & $* * *$ & 0.91 \\
\hline Fat $(\%)$ & $6.61^{\mathrm{A}}$ & $18.18^{\mathrm{B}}$ & $16.17^{\mathrm{C}}$ & $* * *$ & 0.49 \\
\hline Briskets IX-XVIII & $4.49^{\mathrm{A}}$ & $6.85^{\mathrm{B}}$ & $5.52^{\mathrm{C}}$ & $* * *$ & 0.08 \\
\hline Meat and bone (\%) & $97.71^{\mathrm{A}}$ & $77.93^{\mathrm{B}}$ & $64.88^{\mathrm{C}}$ & $* * *$ & 0.87 \\
\hline Fat $(\%)$ & $2.62^{\mathrm{A}}$ & $22.57^{\mathrm{B}}$ & $34.78^{\mathrm{C}}$ & $* * *$ & 0.34 \\
\hline Steacks I-VIII & $4.46^{\mathrm{A}}$ & $4.75^{\mathrm{B}}$ & $4.47^{\mathrm{A}}$ & $* *$ & 0.06 \\
\hline Meat and bone (\%) & $69.78^{\mathrm{A}}$ & $94.87^{\mathrm{B}}$ & $95.98^{\mathrm{B}}$ & $* * *$ & 0.91 \\
\hline Fat $(\%)$ & $30.56^{\mathrm{A}}$ & $5.63^{\mathrm{B}}$ & $3.68^{\mathrm{C}}$ & $* * *$ & 0.43 \\
\hline Loin+Steacks IX-XVIII & $9.08^{\mathrm{A}}$ & $8.47^{\mathrm{B}}$ & $11.85^{\mathrm{C}}$ & $* * *$ & 0.14 \\
\hline Meat and bone (\%) & $97.84^{\mathrm{Aa}}$ & $94.47^{\mathrm{Ab}}$ & $73.72^{\mathrm{B}}$ & $* * *$ & 0.97 \\
\hline Fat $(\%)$ & $2.50^{\mathrm{A}}$ & $6.03^{\mathrm{B}}$ & $25.95^{\mathrm{C}}$ & $* * *$ & 0.23 \\
\hline Bacon & $12.50^{\mathrm{A}}$ & $9.60^{\mathrm{B}}$ & $8.57^{\mathrm{C}}$ & $* * *$ & 0.15 \\
\hline Meat $(\%)$ & $67.36^{\mathrm{A}}$ & $49.73^{\mathrm{B}}$ & $58.67^{\mathrm{C}}$ & $* * *$ & 0.89 \\
\hline Fat $(\%)$ & $32.97^{\mathrm{A}}$ & $50.77^{\mathrm{B}}$ & $41.02^{\mathrm{C}}$ & $* * *$ & 0.74 \\
\hline Fore leg & $35.70^{\mathrm{A}}$ & $36.42^{\mathrm{A}}$ & $23.10^{\mathrm{B}}$ & $* * *$ & 0.43 \\
\hline Meat $(\%)$ & $72.80^{\mathrm{Aa}}$ & $75.88^{\mathrm{Ab}}$ & $66.60^{\mathrm{B}}$ & $* * *$ & 0.75 \\
\hline Fat $(\%)$ & $11.38^{\mathrm{A}}$ & $13.32^{\mathrm{a}}$ & $16.75^{\mathrm{Bb}}$ & $* *$ & 1.04 \\
\hline Bone $(\%)$ & $16.15^{\mathrm{A}}$ & $11.28^{\mathrm{B}}$ & $16.30^{\mathrm{A}}$ & $* *$ & 0.88 \\
\hline Tenderloin & 2.56 & 2.55 & 2.77 & $\mathrm{~ns}$ & 0.12 \\
\hline Meat $(\%)$ & 86.62 & 85.60 & 89.37 & $\mathrm{~ns}$ & 2.05 \\
\hline Fat $(\%)$ & 13.72 & 14.90 & 10.30 & $\mathrm{~ns}$ & 1.85 \\
\hline
\end{tabular}

Significance: $* * * \mathrm{p}<0.001, * * \mathrm{p}<0.01, * \mathrm{p}<0.05, \mathrm{~ns}=$ Not significant.

Different letters in the same line show statistical differences ( $\left.{ }^{\mathrm{A}, \mathrm{B}, \mathrm{C}} \mathrm{p}<0.01 ;{ }^{\mathrm{a}, \mathrm{b}} \mathrm{p}<0.05\right)$.

first quality cuts on the carcass of horses slaughtered at 18 months $(\mathrm{p}<0.01)$.

The physicochemical parameters of foals meat are shown in Table 3. The slaughtering age did not have its influence on intramuscular fat content, water holding capacity, post-thawing losses, cooking losses, collagen solubility and Warner Blatzer shear force $(p>0.05)$. The mean intramuscular fat content was similar to those reported by other authors (Devic and Stamenkovic, 1989; Pomianowsky et al., 1994; Sarries and Beriain, 2005; Juarez

Table 3. Chemical composition and rheological properties of meat of foals slaughtered at 6,11 and 18 months

\begin{tabular}{|c|c|c|c|c|c|}
\hline & & Age & & & \\
\hline & 6 months & 11 months & 18 months & Significance & SEM \\
\hline Moisture (g/100 g) & $68.11^{\mathrm{A}}$ & $71.32^{\mathrm{B}}$ & $72.43^{\mathrm{B}}$ & $* *$ & 0.55 \\
\hline Protein $(\mathrm{g} / 100 \mathrm{~g})$ & $23.63^{\mathrm{A}}$ & $21.24^{\mathrm{B}}$ & $20.13^{\mathrm{B}}$ & $* *$ & 0.66 \\
\hline Fat $(g / 100 \mathrm{~g})$ & 2.57 & 3.11 & 3.19 & $\mathrm{~ns}$ & 0.32 \\
\hline $\operatorname{Ash}(g / 100 \mathrm{~g})$ & $1.97^{\mathrm{A}}$ & $1.38^{\mathrm{B}}$ & $1.25^{\mathrm{B}}$ & $* * *$ & 0.11 \\
\hline Water holding capacity (\%) & 20.04 & 19.49 & 18.19 & ns & 0.68 \\
\hline Post-thawing losses (\%) & 7.56 & 7.27 & 7.45 & ns & 0.65 \\
\hline Cooking losses $(\%)$ & 37.22 & 37.92 & 38.66 & ns & 0.89 \\
\hline Collagen solubility (\%) & 27.23 & 21.46 & 23.13 & $\mathrm{~ns}$ & 2.74 \\
\hline WBSF on cooked meat $(\mathrm{kg})$ & 5.10 & 5.31 & 5.64 & ns & 0.23 \\
\hline
\end{tabular}

Significance: $* * * \mathrm{p}<0.001, * * \mathrm{p}<0.01, \mathrm{~ns}=$ Not significant.

Different letters in the same line show statistical differences $\left({ }^{\mathrm{A}, \mathrm{B}} \mathrm{p}<0.01\right)$. 
et al., 2009), although greater than that observed in horses slaughtered at 9 and 12 months by Franco et al. (2011) and lower than that reported by Badiani et al. (1997), which extended this interval to $9.2 \%$ in LD muscle of horses slaughtered between 6 and 10 yrs old. Horses tend to concentrate adipogenesis in the subcutaneous district rather than in the intramuscular one (Rossier and Berger, 1988; De Palo et al., 2012), so this physiological tendency could explain why the slaughtering age did not affect intramuscular fat content. Different results were reported by Sarries and Beriain (2005), as they observed an increasing trend of intramuscular fat with the raise of slaughtering age. They found, investigating meat from horses slaughtered at 16 and 24 months old, that in older animals the longer finishing indoor period could affect these parameters. On the other hand, Franco et al. (2011), studying foals slaughtered at 9 and 12 months old, detected an opposite trend with greater values of intramuscular fat in meat from younger animals. Meat obtained from IHDH horses slaughtered at 6 months displayed lower values of moisture and protein $(p<0.01)$ and greater values of ash $(p<0.001)$. In the present work, the mean moisture content of IHDH foals appeared similar to those reported by Juarez et al. (2009), Lanza et al. (2009), Tateo et al. (2008), Sarries and Beriain (2005), and greater than those reported by Badiani et al. (1997), but lower than those observed by Franco et al. (2011; 2013). Studying the effect of slaughtering age, some authors observed a similar effect of slaughtering age on moisture content, but no differences on protein content were observed in foals meat (Sarries and Beriain, 2005; Franco et al., 2011).

Fatty acid profile is reported in Table 4. Intramuscular fatty acid profile showed the prevalence of SFA $(45.36 \%$ to $44.49 \%$ ), followed by MUFA (28.47\% to $30.56 \%)$ and finally PUFA $(25.41 \%$ to $26.09 \%)$. By studying the intramuscular fat composition of IHDH foals slaughtered at 11 months, Tateo et al. (2008) found the same distribution shown in the present study. These results agreed with results reported by Lanza et al. (2009) and Juarez et al. (2009). Other authors found MUFA (Renon et al., 1977; Badiani et al., 1997; Franco et al., 2013) or PUFA (Payne, 1971; Jankowska et al., 1996) as the predominant fatty acids. No differences were observed in SFA and PUFA concerning slaughtering ages $(\mathrm{p}>0.05)$. On the contrary, MUFA appeared greater in older animals $(\mathrm{p}<0.05)$. Such difference was possibly due to the increasing trend observed in C 14:1 $(\mathrm{p}<0.01)$ and $\mathrm{C} 16: 1 \quad(\mathrm{p}<0.05)$ in relation to age at slaughtering. No differences were found in SFA/MUFA and SFA/PUFA between the experimental groups of this study. Within the SFA, the predominant fatty acid was palmitic (C16:0) which showed to be the most present in horse meat as observed by other authors (Tateo et al., 2008; Lanza et al., 2009) and it was not influenced by slaughtering age ( $p>$
Table 4. Fatty acid profile (\% of fatty acids methyl esters) from LD muscle of foals slaughtered at 6,11 and 18 months

\begin{tabular}{|c|c|c|c|c|c|}
\hline & \multicolumn{3}{|c|}{ Age } & \multirow{3}{*}{ Significance } & \multirow{3}{*}{ SEM } \\
\hline & 6 & 11 & 18 & & \\
\hline & months & months & months & & \\
\hline C 12:0 & $1.55^{\mathrm{a}}$ & $1.28^{\mathrm{b}}$ & $1.25^{\mathrm{b}}$ & $*$ & 0.27 \\
\hline C 14:0 & 5.86 & 5.34 & 5.02 & ns & 0.36 \\
\hline C $14: 1$ & $1.01^{\mathrm{A}}$ & $1.36^{\mathrm{B}}$ & $1.38^{\mathrm{B}}$ & $* *$ & 0.23 \\
\hline C 16:0 & 30.98 & 31.77 & 30.92 & ns & 1.00 \\
\hline C $16: 1$ & $0.81^{\mathrm{a}}$ & $1.11^{\mathrm{b}}$ & $1.16^{\mathrm{b}}$ & $*$ & 0.12 \\
\hline C 18:0 & 7.01 & 7.02 & 7.31 & ns & 0.32 \\
\hline C $18: 1$ & 27.07 & 26.01 & 28.02 & ns & 1.15 \\
\hline C $18: 2$ & 1.01 & 1.27 & 1.15 & ns & 0.21 \\
\hline C 18:2 n6 & 19.01 & 18.82 & 18.91 & ns & 1.09 \\
\hline C 18:3 n6 & 0.55 & 0.66 & 0.71 & ns & 0.17 \\
\hline C 18:3 n3 & 4.30 & 4.50 & 4.62 & $\mathrm{~ns}$ & 0.34 \\
\hline C $20: 4$ n6 & 0.53 & 0.56 & 0.71 & ns & 0.10 \\
\hline$n-3 / n-6$ & 0.22 & 0.23 & 0.23 & ns & 0.02 \\
\hline SFA & 45.38 & 45.36 & 44.49 & ns & 1.51 \\
\hline MUFA & $28.90^{\mathrm{a}}$ & $28.47^{\mathrm{a}}$ & $30.56^{\mathrm{b}}$ & $*$ & 1.01 \\
\hline PUFA & 25.41 & 25.82 & 26.09 & ns & 1.33 \\
\hline SFA/MUFA & 1.57 & 1.60 & 1.44 & $\mathrm{~ns}$ & 0.12 \\
\hline SFA/PUFA & 1.80 & 1.74 & 1.71 & ns & 0.18 \\
\hline
\end{tabular}

Significance: $* * \mathrm{p}<0.01, * \mathrm{p}<0.05, \mathrm{~ns}=$ Not significant.

$\mathrm{SFA}=$ Satured fatty acids; MUFA $=$ Mono-unsatured fatty acids; PUFA = Poly-unsatured fatty acids.

0.05). As observed by Lanza et al. (2009), also in this study, within MUFA, oleic acid was the predominant, the second fatty acid for concentration, after the palmitic one. Linoleic acid represented the third on total fatty acids and the first on PUFA. These results were similar to that observed by Tateo et al. (2008) and Lanza et al. (2009). The linoleic acid levels were higher than those reported in beef (Muchenje et al., 2009) and lambs (Manso et al., 2009). It is well established that, in ruminants linoleic acid was degraded to MUFA and SFA by a microbial biohydrogenation step, leaving only a small proportion available for deposition in lipid tissue. Alternatively, the linoleic acid proportion in the muscle tissue of monogastric strictly depended on the diet because of its unchanging during passage through the gastro-enteric tract, its absorption in small intestine and incorporation in tissues (Wood et al., 2008). However, horse meat showed a great quantity of UFA, and this tended to increase with the slaughtering age, due to the rising of MUFA concentration ( $p<0.05)$. Tateo et al. (2008) stated that, from a nutritional point of view, the meat of IHDH foals was more suitable than veal or beef owing to its high degree of unsaturation of the intramuscular fatty acids. This work confirmed these aspects in all slaughtering age considered.

\section{CONCLUSIONS}

Herein, the trial was carried out to evaluate the 
characteristics of foals meat depending on the slaughtering age, considering a local Italian horse breed (IHDH) particularly indicated for meat production. The age of foals was found to affect only carcass characteristics and traits, nevertheless age did not heavily impact meat quality. The unsaturation index of intramuscular fatty acids was not affected by slaughtering age, thus confirming that horse meat offers a more suitable dietetic value, when compared to beef. By this way, we conclude that conceivably might be possible to produce meat of IHDH foals during the entire year, without registering any negative influence on meat quality.

\section{ACKNOWLEDGEMENTS}

The authors want to thank Dr. Calzaretti Giovanna and Mr. D'Onghia Francesco for their skilled help in meat sampling and in several laboratory analyses.

\section{REFERENCES}

Badiani, A., N. Nanni, P. P. Gatta, B. Tolomelli, and M. Manfredini. 1997. Nutrient profile of horsemeat. J. Food Compost. Anal. 10:254-269.

Bertram, H. C., H. J. Andersen, A. H. Karlsson, P. Horn, J. Hedegaard, L. Nørgaard, and S. B. Engelsen. 2003. Prediction of technological quality (cooking loss and Napole Yield) of pork based on fresh meat characteristics. Meat Sci. 65:707-712.

Bligh, E. G. and W. J. Dyer. 1959. A rapid method of total lipid extraction and purification. Can. J. Biochem. Physiol. 37:911917

Bouton, P. E., P. V. Harris, and W. R. Shorthose. 1971. Effect of ultimate $\mathrm{pH}$ upon the water-holding capacity and tenderness of mutton. J. Food Sci. 36:435-439.

Centoducati, P., A. Maggiolino, P. De Palo, and A. Tateo. 2012. Application of wood's model to lactation curve of Italian heavy draught horse mares. J. Dairy Sci. 95:5770-5775.

De Palo, P., A. Maggiolino, P. Centoducati, and A. Tateo. 2012. Colour changes in meat of foals as affected by slaughtering age and post-thawing time. Asian-Aust. J. Anim. Sci. 25:17751779.

De Palo, P., A. Maggiolino, A. Lestingi, and A. Tateo. 2009. Comparison between carcasses of artificially suckled I.H.D.H. (Italian Heavy Draught Horse) foals slaughtered at 6 months and traditional carcasses obtained by foals slaughtered at 11 and 18 months. Ital. J. Anim. Sci. 8:700-702.

Devic, B. and T. Stamenkovic. 1989. Basic characteristics of the horse meat and the possibilities for its processing. Tehnologia Mesa 30:232-237.

Franco, D., S. Crecente, J. A. Vazquez, M. Gomez, and J. M. Lorenzo. 2013. Effect of cross breeding and amount of finishing diet on growth parameters, carcass and meat composition of foals slaughtered at 15 months of age. Meat Sci. 93:547-556.

Franco, D., E. Rodriguez, L. Purrinos, S. Crescente, R. Bermudez, and J. M. Lorenzo. 2011. Meat quality of "Galician Mountain" foals breed. Effect of sex, slaughter age and livestock production system. Meat Sci. 88:292-298.

ISO (International Organization for Standardization). 1973. Determination of total fat content. ISO R-1443-1973. International Standards Meat and Meat products. Genève, Switzerland: International Organization for Standardization.

ISO (International Organization for Standardization). 1998. Determination of ash content. ISO R-936-1998. International Standards Meat and Meat products. Genève, Switzerland: International Organization for Standardization.

ISO (International Organization for Standardization). 1978. Determination of nitrogen content. ISO R-937-1978. International Standards Meat and Meat products. Genève, Switzerland: International Organization for Standardization.

Jankowska, B., W. Korzeniowski, and A. Kwiatkowska. 1996. Fatty acid composition of horse's tissue depending on their position in the carcass. Pol. J. Food Nutr. Sci. 5:41-49.

Juarez, M., O. Polvillo, M. D. Gomez, M. J. Alcalde, F. Romero, and M. Varela. 2009. Breed effects of carcass and meat quality of foals slaughtered at 24 months of age. Meat Sci. 83:224-228.

Kindt, E., K. Gueneva-Boucheva, J. Rekhter, M. D. Humphries, and H. Hallak. 2003. Determination of hydroxyproline in plasma and tissue using electrospray mass spectrometry. J. Pharm. Biomed. Anal. 33:1081-1092.

Lanza, M., C. Landi, M. Scerra, V. Galofaro, and P. Pennisi. 2009. Meat quality and intramuscular fatty acid composition of Sanfratellano and Haflinger foals. Meat Sci. 81:142-147.

Lombardi-Boccia, G., S. Lanzi, and A. Aguzzi. 2005. Aspects of meat quality: Trace elements and $\mathrm{B}$ vitamins in raw and cooked meats. J. Food Compost. Anal. 18:39-46.

Manso T., R. Bodas, T. Castro, V. Jimeno, and A. R. Mantecon. 2009. Animal performance and fatty acid composition of lambs fed with different vegetable oils. Meat Sci. 83:511-516.

Martuzzi, F., A. L. Catalano, and C. Sussi. 2001. Characteristics of horse meat consumption and production in Italy. Annali della Facoltà di Medicina Veterinaria (Vol. 21). Italy: University of Parma. 213-233.

Muchenje, V., A. Hugo, K. Dzama, M. Chimonyo, P. E. Strydom, and J.G. Raats. 2009. Cholesterol levels and fatty acid profiles of beef from three cattle breeds raised on natural pasture. J. Food Compost. Anal. 22:354-358.

Payne, E. 1971. The use of fatty acid composition of lipids in identification of horse and kangaroo meat. J. Sci. Food Agric. 22:250-522.

Pomianowski, J. F., W. Rotkiewicz, and J. Borowski. 1994. Quality of selected culinary goods with addition of horsemeat. Acta Academiae Agriculturae ac Technicae, Olestensis Technologia Alimentorum 26:63-70.

Renon, P., G. Comi, and C. Canton. 1979. Acides gras du tissue adipeux de cheval. Archivio Veterinario Italiano, 30:35-40.

Rossier, E. and C. Berger. 1988. La viande de cheval: des qualities indiscutables et pourtant meconnues. Cahiers de nutrition et de diététique, 23:35-40.

Sarriés, M. V. and M. J. Beriain. 2005. Carcass characteristics and meat quality of male and female foals. Meat Sci. 70:141-152.

SAS 1998. Applied statistics and the SAS programming language. Cary, NC, USA: SAS Institute Inc.

Sörensen, S. E. 1981. Relationship between collagen properties and meat tenderness in young bulls of different genotype, weight and feeding intensity. $\mathrm{PhD}$ Thesis. The Royal 
Veterinary and Agricultural University, Department of Meat Science and Technology, Copenhagen, Denmark.

Tateo, A., P. De Palo, A. Maggiolino, and P. Centoducati. 2013. Post-thawing changes in meat of foals as affected by feeding level and post-thawing time. Arch. Tierz. 56. doi: 10.7482/0003-9438-56-029.

Tateo, A., P. De Palo, E. Ceci, and P. Centoducati. 2008. Physicochemical properties of meat of Italian Heavy Draft horses slaughtered at the age of eleven months. J. Anim. Sci. 86:1205-1214.

Tateo, A., P. De Palo, B. Padalino, and P. Centoducati. 2009 Artificially suckled I.H.D.H. (Italian Heavy Draught Horse) foals: In vivo performances and ethograms. Italian J. Anim. Sci. 8:724-726.
Tateo, A., P. De Palo, B. Padalino, and P. Centoducati. 2005. Quality of carcasses in I.H.D.H. foals reared in the province of Bari (Italy). Italian J. Anim. Sci. 4:418-420.

Wood, J. T., M. Enser, A. V. Fisher, G. R. Nute, P. R. Sheard, R. I. Richardson, S. I. Hughes, and F. M. Whittington. 2008. Fat deposition, fatty acid composition and meat quality: A review. Meat Sci. 78:343-358.

Znamirowska, A. 2005. Prediction of horse carcass composition using linear measurements. Meat Sci. 69:567-570.

Znamirowska, A. and R. Stanislawczyk. 2005. Effect of maturing process on changes in physico-chemical properties of colt meat. Acta Sci. Pol. Technol. Aliment. 4:79-88. 